\title{
1. Implications of shareholder activism
}

\section{Anita Anand}

\subsection{INTRODUCTION}

Shareholder activism has become an increasingly conspicuous aspect of capital market activity. The term 'activist investor' describes an investor, often a hedge fund, which seeks to acquire significant minority positions in undervalued public companies. The investor may thereafter seek value-enhancing changes in the leadership, governance, capital structure or strategy and operations of the corporation. Such activism engages several aspects of corporate and securities law. Is the relevant law in need of amendment?

In answering this question, a starting point is Berle and Means' (1933: 6) argument that the modern corporation is one characterized by the separation of ownership and control, given that 'the position of ownership has changed from that of an active to that of a passive agent' ${ }^{1}$ The rise of activist shareholders over the past 25 years undermines Berle and Means' conclusion: these shareholders are anything but passive. ${ }^{2}$ They are sophisticated, often seeking governance changes over and above those that yield a mere return on their investment.

Gilson and Gordon (2013: 863) argue that the rise of shareholder activism has led to a 'reconcentration of ownership in the hands of institutional investment intermediaries'. Yet this claim does not capture the full gamut of activist pressure. Activists may engage in one of two types of activism: offensive activism initiated by hedge funds primarily in response to poor corporate performance of potential targets, or defensive activism involving institutional activists who take on an advocacy role when they are unhappy with the corporation in which they are invested

\footnotetext{
1 For an historical analysis of Berle and Means' thesis about separation of ownership and control, see Stout (2013).

2 See Gilson and Gordon (2013). Stout (2013: 1178) states, 'Shareholders now have more influence over boards, and executives now are more focused on share price, than at any time in business history'.
} 
(Cheffins and Armour 2011). Both offensive and defensive activists seek to participate in the governance of the corporation ex ante. They view shareholder participation as necessary because of the marked tendency for management to perpetuate itself in office (Kimber Report 1965).

Currently, securities and corporate law address this issue by allowing shareholder proposals and requisitions, as well as compelling corporations to provide shareholders with proxy forms and information circulars' prior to every annual meeting. The law also permits shareholders to put forward motions by circulating a separate or 'dissident' information circular (Securities Act (Ontario), s. 86; ${ }^{3}$ NI 51-102 (Canada); ${ }^{4}$ Canada Business Corporations Act, s. 150). But activists argue that these corporate law rules are insufficient; legal changes to ensure less management entrenchment and more meaningful shareholder participation in the corporation are required.

'Shareholder democracy', or the ability of shareholders to influence the corporation through their vote, is an important concept in corporate law; it underpins the legitimacy of shareholder activism. But shareholder democracy is not a static concept. Jurisdictions can experience more or less shareholder democracy depending on the substantive content of their respective corporate law statutes. Examining the relevant empirical literature, this chapter argues in favour of increased shareholder democracy in terms of shareholder representation in director nominations, in order to make the existing right to elect directors meaningful: a right to elect directors has little point if shareholders do not also have some say in choosing the candidate for whom they are voting.

Section 2 explores the concept of shareholder democracy as the main justification for increased shareholder activism. Section 3 analyses the main argument against increased shareholder democracy, namely, 'shorttermism' on the part of hedge funds. Section 4 responds to the question of whether corporate law is adequate. It examines whether reform is necessary and, if so, what type of reform in particular is needed. The focus of the discussion is on proxy access. Section 5 concludes with arguments in favour of granting shareholders the right to nominate candidates for director elections.

3 RSO 1990, c. S 5.

4 NI 51-102, Continuous Disclosure Obligations (2012). 


\subsection{SHAREHOLDER DEMOCRACY}

The separation of ownership and control is a characteristic of many modern public corporations (Berle and Means 1933). While shareholders, as corporations' owners, ${ }^{5}$ may seek to maximize the value of their residual claim, managers may shirk their duties or divert corporate resources to their own benefit at the expense of shareholders (Jensen and Meckling 1976). According to Jensen and Meckling, these divergent interests can lead to agency costs: costs that shareholders incur to ensure that directors and managers do not place their own interests above the corporation's (ibid.; see also Bebchuk 2006b). Agency costs arise when directors' and officers' interests do not align with shareholders' interests.

Considering the potential for agency costs to arise, shareholders may be inclined to monitor the actions of directors and managers, especially since these individuals, as rational actors, may seek to entrench themselves. Some argue, contrary to empirical evidence (on this see Bebchuk and Kamar 2010; Borochin and Knopf 2016), that managers do not entrench themselves (Bainbridge 2003; Chandler 1977). However, the important point is that it is possible for managements to prioritize their own interests above those of corporations: as long as this possibility exists, management entrenchment remains relevant (Anand 2015).

Shareholder democracy - the idea that shareholders are able to influence corporate affairs through their vote - undermines the potential for entrenchment and agency costs. The two are inversely related. That is, the greater the shareholder democracy, the less entrenchment there will be. Thus, the question is where on the scale a legal regime is situated given the balance of power between the board of directors and shareholders (Cassim 2012). This concept can be illustrated by Figure 1.1, which we can call the 'Shareholder Democracy Scale' (SDS).

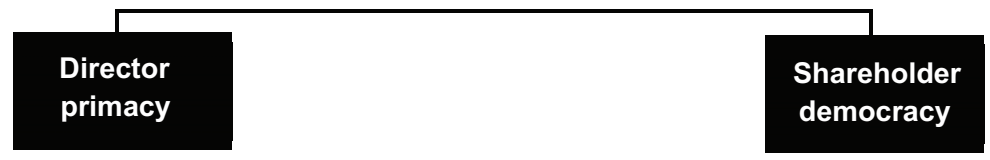

Figure 1.1 Director primacy and shareholder democracy, as polar concepts

5 Although it is not uncontroversial to refer to shareholders as the 'owners' of the corporation, the theoretical concerns raised by Berle and Means remain relevant (see Stout 2012). 
Some believe that shareholders should have a greater voice in corporate governance in order to ensure that management and the board act in shareholders' interests. Bebchuk (2006a), for example, has advocated greater powers for shareholders to remove directors; to nominate directors on the corporate ballot; to vote by secret ballot; to initiate changes to corporate charters; and to vote on compensation. The benefit of these reforms would accrue to shareholders, of course, but would also induce 'management to act in shareholder interests without shareholders having to exercise their power to intervene' (Bebchuk 2005: 833; see also Backer 2006).

By contrast, those who favour director primacy argue for retention of powers in boards and indeed more insulated boards, believing that facilitating shareholder democracy, and thereby shareholder power, would create costs that would outweigh the purported benefits (Hayden and Bodie 2010: 2076). As Lipton and Savitt (2007: 733) argue, proposals for shareholder empowerment would:

transfer the basic responsibility of corporate management from directors to shareholders. And ... leave management and directors subservient to the whims of shareholders ... no matter how inconsistent with long-term corporate performance, and no matter how destructive to the economy as a whole.

In other words, Lipton and Savitt favour less shareholder involvement in corporations so that boards can serve corporations as they are legally required to do.

The Bebchuk-Lipton debate highlights the potential for polarization when analysing shareholder democracy. However, those in each camp probably recognize that corporations can be subject to more or less democracy depending on the corporate statute. The debate is over as to where on the Shareholder Democracy Scale a jurisdiction should sit.

In practical terms, Canada's corporate law regime sits somewhere in between the two poles (see Figure 1.2), likely closer to director primacy, because Canadian corporate law grants boards the power to act in the best interests of the corporation (Canada Business Corporations Act, s. 122) but does not favour director primacy to the exclusion of shareholders' influence altogether. In particular, shareholders can make written proposals for consideration by management, requisition meetings if they hold a certain minimum percentage of votes, and bring actions for conduct that is oppressive or unfairly prejudicial to their interests (Canada Business Corporations Act, ss. 137, 143, 241). Recently proposed amendments will mandate majority voting among other reforms 
designed to increase shareholder participation in corporations (Innovation, Science and Economic Development Canada 2016).

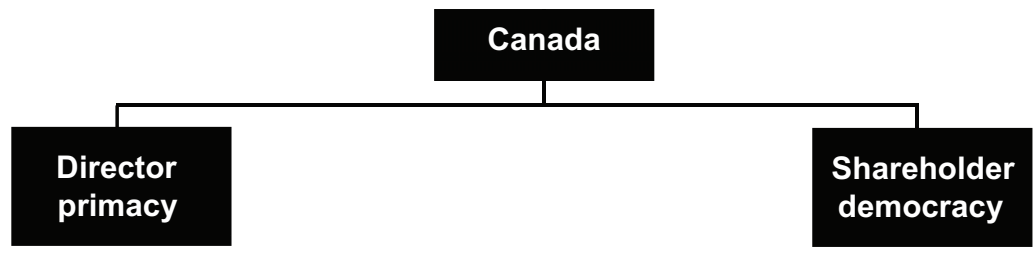

Figure 1.2 Director primacy and shareholder democracy, Canada at midway

We can argue, therefore, that Canada's legal regime supports shareholder democracy to some extent, allowing shareholders to have some influence in the governance of corporations. The important role of shareholders is most evident in recent reforms to takeover bid law under which bids are subject to a mandatory (that is, unwaivable) minimum tender condition of more than 50 per cent of all outstanding voting securities of targets, excluding those already held by the bidder and its joint actors. Bids can, therefore, only succeed with the support of a majority of independent shareholders. In essence, a bidder must obtain a majority of the shares held by others before it can take up shares (NI 62-104). ${ }^{6}$

By contrast, law in the United States, particularly Delaware, affords more deference to the business judgement of directors, providing them with a great deal of flexibility in making unfettered decisions (see generally Ontario Securities Commission 2013, Sch A). ${ }^{7}$ Under Delaware law, if a court determines that a board of directors acted in good faith and in accordance with its fiduciary duties, the board is legally entitled to preserve the long-term strategic goals of the corporation. This is true even if a majority of shareholders favours an alternative approach (Paramount Communications Inc. v. QVC Network Inc., 2011). ${ }^{8}$ In a

\footnotetext{
6 NI 62-104, Takeover Bids and Issuer Bids (2016).

7 In the United Kingdom, the City Code on Takeovers and Mergers places many more restrictions on target boards than would apply in Canada. The Ontario Securities Commission (2013: 17) noted that the UK Code 'prohibits a target company board from taking any action during a bid, or in anticipation of a bid, that would frustrate the take-over bid or otherwise deny shareholders the opportunity to decide on its merits, unless such action is approved by target company shareholders in the face of the bid'.

${ }_{8} 637$ A2d 34 (Del. 1994), Civil Action No. 5249-CC (Del.) (Ch. 2011)
} (QL). 
takeover bid situation, for example, US boards are entitled to 'just say no' to a proposed bid and to use defensive tactics, such as poison pills, to prevent (as opposed to simply delay) a bid (Kahan and Rock 2007). Once it becomes apparent that the target company will be sold or broken up, however, the board's duty shifts to maximizing shareholder value, either by negotiating for improved bid terms or by seeking out and proposing an alternative transaction (Revlon Inc. v. MacAndrews \& Forbes Holdings Inc., 1986). ${ }^{9}$ US law would thus fall closer to the director primacy side on the SDS (see Figure 1.3).

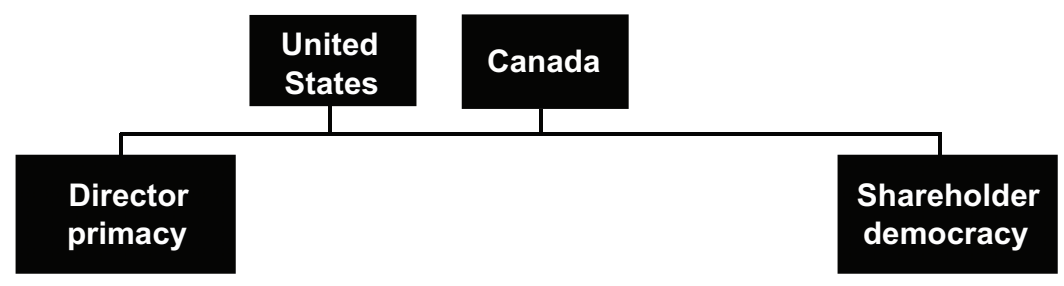

Figure 1.3 United States leaning towards director primacy

Bebchuk and Lipton would likely agree that the debate about shareholder democracy is about the extent to which we wish to carve out directorial power in favour of increased shareholder decision-making. But they disagree about where on the SDS corporate law should situate itself.

We must note that directors and other insiders are often themselves shareholders. So the implication is that the shareholders to whom the debate applies are outside shareholders who can be 'activists'; these shareholders play a particular role in corporations and serve useful purposes. It is to an analysis of these benefits that we now turn.

\subsection{SHAREHOLDER ACTIVISM AND MONITORING}

The Shareholder Democracy Scale illustrates that there may be more or less shareholder democracy depending on the legal regime in question. This point must be remembered when considering shareholder activism. To begin, this section discusses the monitoring role that activists play and the effect of activism on corporations. While activists monitor management, they are also criticized for having short-term focus.

9506 A2d 173 (Del. 1986). 


\subsubsection{Monitoring Role}

The presence of a shareholder that owns a sizeable percentage of a corporation's equity - an activist - can mitigate agency costs through two mechanisms that discipline management, namely, 'voice' and 'exit' (Edmans 2014; Hirschman 1970). ${ }^{10}$ Of these, 'voice' involves the activist's direct intervention in the firm, often through letters to management, shareholder proposals or the exercise of control or voting rights (Edmans 2014: 24). Accordingly, managers are compelled to act in the interests of shareholders (or at least those of the activist) out of fear of replacement. 'Exit' involves the sale of the activist's shares. The sale can have the effect of driving down the firm's share price, thereby punishing management, ex post (ibid.). The threat of exit imposes ex ante discipline on managers.

The role that the activist plays in monitoring management and the board is central to its decision to exercise voice or exit. The larger the activist, the more readily it can absorb the cost burden of monitoring; its sizeable position in the corporation gives it added 'skin in the game' to ensure that management is held accountable (Bebchuk 2012: 47). The activist intervenes when the costs of intervention are outweighed by the private benefits of doing so.

Empirical evidence suggests that there is a positive, or at least a neutral, relationship between activists and firm value (Cronqvist and Fahlenbrach 2009; Edmans 2014; Holderness 2003). The presence of activists is associated with improved outcomes for shareholders on matters ranging from executive compensation to the facilitation of takeover bids (Bebchuk 2012). The benefits provided by the activist's monitoring flow through to other shareholders, who are able to free-ride on the large shareholder's activism.

Of course, the incentives for activists to monitor (including their willingness to internalize the costs of free-riding) vary with the size of their block (Winton 1993). Small investors can only absorb a negligible share of the firm's risk, leaving them with insufficient incentives to monitor (ibid.). Put another way, only large activists will monitor firms with high monitoring costs (Dhillon and Rossetto 2009). Evidence further suggests that multiple small activists are not as effective in influencing corporate decision-making as single large activists, partly because coordination costs between the small activists impede their

10 For a seminal theoretical paper on the role of activists in reducing agency costs, see Shleifer and Vishny (1986). 
ability to monitor the firm (Winton 1993). As such, a group of small shareholders that collectively owns a block of shares equivalent in size and right to a block owned by a single large activist will likely result in less effective monitoring (Armour et al. 2009). ${ }^{11}$ It is simply more difficult to organize behaviour among a group of dispersed shareholders (Kulpa 2005), especially when shareholders have heterogeneous preferences (Armour et al. 2009). ${ }^{12}$

In short, the presence of a single activist can have a beneficial effect on the firm's governance in reducing agency costs through monitoring. At the same time, however, blocks comprised of multiple small activists may be less effective at fulfilling the role of the activist in the corporation.

\subsubsection{Short-Termism}

While activists play an important monitoring role in corporations, they are subject to a standard criticism, namely, 'short-termism'. This refers to the claim that they are concerned only with the short-term (as opposed to the long-term) interests of the corporation. But looking out for the short term is not necessarily inconsistent with doing the same in the long term, especially when inefficient leadership is at the helm of the corporation.

The foremost goal of an activist, and particularly a hedge fund activist, is to maximize investors' returns (Gad 2013). As unregulated entities, hedge funds search for and invest in high-yield products and projects on behalf of clients who have entrusted their money to the fund (Bennelong 2013). While hedge funds may focus on the short term to maximize their immediate returns, the focus may well coincide with the long-term interests of corporations.

The case of Canadian Pacific Railway (CP) is instructive. In 2008, CP Rail's performance began to lag behind other major North American railways. For example, by the end of 2008, CP Rail's operating ratio sat

11 Although the presence of a single large activist tends to increase shareholder monitoring of management, it is worth bearing in mind the possibility that the activist will seek to extract private benefits of control to the detriment of other shareholders.

12 It is worth noting, however, that the coordination issues that hinder shareholder intervention strategies actually make the threat of exit stronger, thereby allowing many small activists to have a positive impact on managerial discipline: Edmans and Manso (2010) argue that the threat of trading activity of multiple activists in the face of poor managerial performance disciplines management. Even so, wolf packs ostensibly form to intervene and agitate for change, not to passively invest and then exit. 
at 80 per cent, whereas in comparison Canadian National (CN) Rail's operating ratio was only 66 per cent. In 2011, Pershing Square Capital Management, a hedge fund, formally announced that it had acquired 12 per cent of CP's shares. CP appointed two new board members and offered a board position to Bill Ackman, founder and CEO of the activist shareholder Pershing Square. Ackman rejected the offer and Pershing initiated a proxy battle, eventually proposing a slate of seven new directors. During the battle, the sitting CP board continued to support then-CEO Fred Green, whereas Pershing Square proposed Hunter Harrison, former CEO of CN. Citing the company's poor performance, CP's major shareholders publicly declared support for Pershing's director slate. Six CP board members, including Green, declined to stand for re-election. The Pershing slate was elected to the board, and Harrison was appointed CEO (Jang 2013a).

Pershing's actions served the long-term interests of CP. Even after Pershing divested about one-third of its 24 million shares (which represented a 14.2 per cent stake in CP) in October 2013, CP stock closed at CAD\$147.95 a share, which was more than triple their level when Pershing began purchasing CP shares. Jang (2013b) reported:

Harrison has led a turnaround at CP, narrowing the efficiency gap between it and rival CN. Analysts have been surprised at the pace of CP's improvements, including achieving faster average train speeds and reducing the time that locomotives are parked in rail yards.

At the time, CP's third-quarter profit was CAD\$324 million, the best quarterly results in the corporation's history (ibid.).

The CP Rail example suggests that shareholder activism can be positive for corporations. For example, a 2010 victory by Lionsgate management over shareholder activists was followed by a share price increase of more than 100 per cent over the next two years, ${ }^{13}$ while a victory by EnerCare Inc management also saw share price significantly increase over the next two years. ${ }^{14}$ But we would be remiss to believe that activism has been uniformly beneficial for corporations; other proxy contest data has yielded mixed results (Atkinson et al. 2013). However, a

13 Lionsgate enacted a poison pill provision in 2010 to discourage a shareholder's 'creeping bid'. After implementation, Lionsgate's share price increased from CAD\$7.00 to CAD\$14.80.

14 In 2012 EnerCare offered to pay brokers a solicitation fee of CAD \$0.05 for each share voted by a retail shareholder in favour of board re-election. EnerCare's share price improved from CAD\$9.90 in April 2012 to CAD $\$ 15.85$ in April 2016. 
victory by the management of Baja Mining Corporation over shareholders was followed by a 99 per cent decrease in share price (share price data from TMX Money (2013)). Meanwhile, a victory by shareholder activists over the management of Hudbay Minerals was followed by a subsequent share price decrease, in contrast to the example of CP above (ibid.). These examples are consistent with the argument of Rose and Sharfman (2014) that shareholder activism can provide value; however it should be considered on a case-by-case basis.

The evidence is also mixed with respect to mergers or takeovers following proxy contests. There have been some cases where shareholder activists have won (or partially won) a proxy battle, but a merger or takeover followed. For example, Biovail merged with Valeant Pharmaceuticals following a partial victory by shareholder activists. Pet Valu was also involved in a merger following a victory by shareholders in a proxy contest. This is not to say that a merger or acquisition will always occur after a shareholder victory in a proxy contest, as the example of HudBay Minerals, discussed earlier, demonstrates. It was not involved in an acquisition or merger.

While shareholder activism may not be uniformly beneficial for corporations, when it yields benefits, these accrue to all shareholders, not only to the activist or hedge fund. Carrothers (2013) points out that the average abnormal return at target firms in the 20 days surrounding the disclosure of activist intentions is 7.1 per cent, and the average buy and hold abnormal return in the 20 months after the disclosure is 23 per cent. Similarly, Bebchuk et al. (2015) found a 6 per cent abnormal return in stock price during the 40-day period straddling the announcement of an activist campaign. This result was not offset by a subsequent long-term decrease in stock price (ibid.). In short, it appears that the market as a whole can benefit from positive responses to hedge fund activism (ibid.).

Consistent with the position described above, Katelouzou (2013: 504) argues that the:

dark side of hedge fund activism is largely a myth: activist hedge funds are not short-term investors ... [the] evidence makes a case for hedge fund activism as a value-enhancing corporate governance mechanism which could plausibly be corporate governance relevant.

Target share price movement following a proxy contest suggests that shareholder activism, including the ability to assert a position that differs from management via dissident nominees, can be good for firms.

The point here is that shareholder activists play a useful monitoring role in target corporations and their activities can benefit shareholders at 
large, not just themselves. The argument that activists are only focused on the short term is, therefore, somewhat of a diversion, especially when we consider that there are long-term benefits associated with activism.

\subsection{PROXY ACCESS AND ITS DIMENSIONS}

If it is the case that shareholder activism can be beneficial for corporations, the question arises as to how the law should address it. The first step in answering this question is by recognizing that the shareholders seeking to gain more power in corporations are likely to be minority shareholders unless a corporation is widely held, which is not generally the case in Canada. The discussion about reform, therefore, is largely with reference to the rights of minority shareholders.

To begin, recall that the concept of shareholder democracy contemplates that shareholders should be able to participate in the governance of corporations. Shareholder participation is believed to be necessary because of the risk of management entrenchment (Kimber Report 1965). The ultimate question, and the one debated by Bebchuk (2006b) and Lipton and Savitt (2007), is how much participation is necessary to counter the potential for entrenchment? To deal with the issue, this section explores proposals for increased 'proxy access'.

\subsubsection{Proxy Access}

Those who favour 'proxy access' argue that shareholders should not only be able to elect directors, but also to nominate them for election. They contend that nominees of shareholders should be placed on the same ballot as management nominees. The intended goal of this reform would be to increase the levels of independence and quality of boards of directors, while providing shareholders with a meaningful say in who is able to become a director. Thus, at issue is the nomination process available to shareholders.

One can easily concede that shareholders have statutory rights that enable them to nominate directors. Among the various shareholder rights discussed above, some of them enable shareholders to nominate directors. First, the shareholder proposal mechanism can include director nominations (Canada Business Corporations Act, s. 137(4)). ${ }^{15}$ This is part

15 For example, in National Bank v. Weir 2009 QCCS 5688, the Quebec Superior Court granted a motion by National Bank to exclude 38 proposals by a shareholder in the Management Proxy Circular under the Bank Act (SC 1991, c. 
of the broader process for submitting shareholder proposals to corporations and exists independent of the securities law rules relating to proxy contests. Second, shareholders holding more than 5 per cent of the corporation's shares can also requisition a meeting to nominate a director (s. 143). But again, this can be an expensive process with no guarantee that management will accept the proposal or requisition. Also for shareholders who hold less than 5 per cent, this legislative provision is not helpful. Third, shareholders can go through the dissident proxy process, but this too is an expensive endeavour that only wealthy shareholders have utilized (CCGG Policy 2015).

While some may argue that the shareholder provisions cited above evidence a shareholder-centric bias (see, for example, Vanderpol and Waitzer 2012), we may reasonably respond that shareholders' ability to elect directors has little meaning if they do not have a definite say over which names appear on the ballot in the first place. No statutory provision exists that enables them to do that explicitly and directly (Bebchuk 2005). ${ }^{16}$

Some may argue that directors nominated by a shareholder will be beholden to the shareholder rather than the corporation as a whole. But this claim is unpersuasive; directors - regardless of who nominated them - have a duty to act in the best interests of the corporation (Canada Business Corporations Act, s. 122). Current directors continuously face conflicts in the course of discharging their duties, but, as fiduciaries, they are obliged by law to rise above such conflicts. To argue that directors nominated by certain shareholders would be unable to rise to the legal

46) proposal provisions, namely, s. 143(5)(b) and (e), which are virtually identical to the proposal provisions in s. 137(5)(b) and (e) of the Canada Business Corporations Act (RSC 1985, c. C-44). The court held that although a proposal may appear to be neutral on its face, it must be read and considered in context. The court found that in light of the timing and circumstances, it was evident that the proposals by the respondent were abusive, even though in normal circumstances these 'might be considered his rights as shareholder'. The court also noted that there was not an abundance of case law on this subject since the proposal mechanism was rarely used in Canada until recently.

16 Supporters of 'management insulation' will counter this argument and assert that shareholders should not be given the right to nominate directors, since shareholder interests in the corporation are often short term as opposed to long term, and in general are motivated by considerations other than enhancing the corporation's long-term interests. Those concerned with the possibility of increased shareholder power may also argue that shareholder nomination power could lead to the board being 'co-opted' and represent the interests of a particular shareholder rather than the corporation as a whole. 
standard required of them suggests that these directors, and directors generally, are unable to separate their personal interests from their duty to corporations. Why are shareholder nominees any different from the director population at large, many of whom are employed by or represent related parties, such as controlling shareholders or management?

Some may argue that according this right to shareholders would lead to a shareholder or a group of shareholders taking control of the board over time. Thus some type of cap seems reasonable. One proposal is to allow shareholders, for example if they hold 3-5 per cent of the corporation's outstanding shares, to have a circumscribed right, such as being able to nominate the lesser of three directors or 20 per cent of the board (CCGG 2015). Another possibility is to enable minority shareholders who have held a certain percentage of shares over a certain period of time to name at least one nominee on every slate presented to shareholders at annual shareholder meetings, with information about each of these nominees being included in proxy materials containing information on corporations' nominees. ${ }^{17}$

Reforms that give shareholders the ability to nominate directors by proxy should not be based solely on achieving enhanced shareholder democracy, but also on the benefits these reforms will have on corporations and corporate governance as a whole. In other words, there does not have to be a gap between those who wish to see increased shareholder democracy, on the one hand, and those who are concerned about the wellbeing of the corporation, on the other. ${ }^{18}$ We turn now to consider some of the advantages of increased shareholder democracy for the corporation.

17 This is currently the system in Italy. See Canadian Coalition for Good Governance (2015) for other international examples. See also Skeel et al. (2011) for more details on the Italian system.

18 Bratton (2016) makes a similar point - that the existing chasm between those for and against shareholder activism is not necessary - but advances a much different reform proposal. Bratton's idea revolves around asking the question whether a 5 per cent poison pill can have policy benefits. He states, 'Some [companies] are appropriate targets for activist intervention, while others are not ... company-by-company dialogue on the point would be a good thing, exploring the possibility that a 5 per cent standing pill could trigger useful informational exchanges between managers and institutional investors without simultaneously over-deterring activist intervention'. 


\subsubsection{Advantages of Proxy Access for the Corporation}

A number of advantages result from proxy access. First, shareholder presence on the board can be an antidote to 'groupthink' norms that suppress innovation and dissent. Some argue that groupthink has been a factor in corporate scandals (for example, Enron) and helps to explain the passivity of corporate boards (Murphy 2011). It is argued that corporations need the shareholders to supply them with directors who will not hesitate to bring different viewpoints to boardroom tables. The alternative - no direct, non-discretionary inputs from shareholders into the nomination process - will do little to dispel the current apprehension regarding management and board entrenchment, and, more importantly, will do little to change prevailing corporate governance processes that at times have been at the root of corporate scandals and failures.

Second, shareholder representation can be a way to increase board independence, expertise and effective risk management. Murphy (2009: 474) argues that 'shareholder participation in corporate governance can help give the chair [of the board] the independence necessary to carry out an effective leadership role'. In addition, shareholder-nominated directors could have a depth of expertise that would allow them to possess the necessary qualifications required to serve on various committees of the board. They will be able to ally themselves with other directors who are independent of management (Murphy 2009: 472). Finally, greater shareholder participation in the nomination process could help avoid having a board that is unqualified (Murphy 2011).

Third, the evidence that shareholder activism can lead to an increase in a corporation's value suggests that formally enhancing shareholder participation in the nomination process could also be beneficial to corporations. As mentioned in section 3 above, studies demonstrate that shareholder activism has led to increases in corporate value, output and performance. Bebchuk (2013), for example, describes how target companies underperforming during the two years prior to an intervention subsequently recovered in the two years after the intervention without any evidence of adverse long-term effects. Bebchuk's finding of the positive stock price reaction to interventions in the short and long term suggests that greater shareholder representation and involvement in nominating directors could benefit corporations.

Admittedly, acknowledging the importance of shareholder democracy may divert us from the comfort sought in entrusting boards of directors with charting corporations' courses. Remember, however, that, consistent with the Shareholder Democracy Scale, shareholder democracy seeks that a balance be struck between boards of directors and shareholders. The 
shareholder activist movement suggests that the balance in corporate statutes is tilted too far in favour of boards. But there are legitimate arguments on both sides of the debate. Ultimately, with regard to proxy access, it is a question of making the existing right of shareholders to elect directors meaningful: what is the point of a right to elect if shareholders do not also have some say in the choice of the person for whom they are voting?

\subsection{CONCLUSION}

This chapter posits the Shareholder Democracy Scale as a means to understand the polarizing debate between those who argue in favour of director primacy vis-à-vis shareholder democracy. Shareholders have certain rights already under Canadian corporate law, which means that its regime does not exclusively evidence director primacy. A reform that would give greater meaning to the shareholders' right to elect directors would be granting the accompanying right to nominate directors. The two go 'hand in hand', and conferring the right would not tilt the balance away from directors to a significant degree, especially if a percentage of shareholding criterion were attached to shareholders' ability to so nominate.

\section{REFERENCES}

Anand, A. (2015), 'The Future of Poison Pills in Canada: Are Takeover Bid Reforms Needed?' 61 McGill Law Journal 1

Armour, J., H. Hansmann and R. Kraakman (2009), Agency Problems, Legal Strategies and Enforcement, Harvard John M. Olin Discussion Paper Series No. 644, available at www.law.harvard.edu/programs/olin_center/papers/pdf/ Kraakman_644.pdf

Atkinson, A.J., D. Batista and B.A. Freelan (2013), '2013 Canadian Proxy Contest Study', Fasken Martineau, available at http://www.fasken.com/en/ canadian-proxy-contest-study_e/

Backer, L.C. (2006), 'Direct Shareholder Democracy: Reflections on Lucian Bebchuk' 2 Corporate Governance Law Review 375

Bainbridge, S.M. (2003), 'Director Primacy: The Means and Ends of Corporate Governance' 97 Northwestern University Law Review 547

Batista, D. (2013), 'Speaking with the Enemy: How the OSC's Dialogue with Martin Lipton Threatens Those Whom the OSC is Charged with Protecting', Lexology (17 October), available at www.lexology.com/library/detail.aspx?g= ce491dc8-5aac-43ab-aaad-3f4bdb79dfad

Bebchuk, L. (2005), 'The Case for Increasing Shareholder Power' 118 Harvard Law Review 833 
- (2006a), 'Investors must have power, not just figures on pay', Financial Times, 27 July

- (2006b), The Myth of the Shareholder Franchise, Harvard John M. Olin Discussion Paper Series No. 567, available at http://sr.nellco.org/cgi/ viewcontent.cgi?article $=1353 \&$ context=harvard_olin

- (2012), 'The Law and Economics of Activist Disclosure' 2 Harvard Business Law Review 39

- (2013), 'The Myth that Insulating Boards Serves Long-Term Value' 113 Columbia Law Review 1637

Bebchuk, L., B. Alon and W. Jiang (2015), 'The Long-term Effects of Hedge Fund Activism' 115 Columbia Law Review 1085

Bebchuk, L. and E. Kamar (2010), Bundling and Entrenchment, Harvard John M. Olin Discussion Paper Series No. 659, available at www.law.harvard.edu/ programs/olin_center/papers/pdf/Bebchuk_659.pdf

Bennelong (2013), 'Debunking Hedge Fund Myths', Century Private Wealth, available at www.centuryprivatewealth.com.au/news/view/debunking_hedge_ fund_myths

Berle, A. and G. Means (1933), The Modern Corporation and Private Property (MacMillan, rev edn 1967)

Borochin, P. and J.D. Knopf (2016), 'Do Managers Seek Control and Entrenchment?' (7 October), available at http://papers.ssrn.com/sol3/papers.cfm? abstract_id=2670918

Bratton, W.W. (2016), 'Hedge Fund Activism, Poison Pills and the Jurisprudence of Threat', CLS Blue Sky Blog, Columbia Law School (6 October), available at http://clsbluesky.law.columbia.edu/2016/10/06/hedge-fund-activism-poisonpills-and-the-jurisprudence-of-threat/

Canadian Coalition for Good Governance (CCGG) (2015), 'Shareholder Involvement in the Director Nomination Process: Enhanced Engagement and Proxy Access', available at www.ccgg.ca/site/ccgg/assets/pdf/proxy_access_finalv. 35.docx_630.pdf

Carrothers, A. (2013), 'Friends or Foes? Activist Hedge Funds and Other Institutional Investors', McMaster University deGroote School of Business, available at www.degroote.mcmaster.ca/articles/friends-or-foes-activist-hedgefunds-and-other-institutional-investors/

Cassim, F.H.I. (2012), 'The Division and Balance of Power between the Board of Directors and the Shareholders: The Removal of Directors' 29 Banking and Finance Law Review 151

Chandler, A.D. (1977), The Visible Hand: The Managerial Revolution in American Business (Harvard University Press)

Cheffins, B.R. and J. Armour (2011), 'The Past, Present, and Future of Shareholder Activism by Hedge Funds' 37 Journal of Corporation Law 51

Cronqvist, H. and R. Fahlenbrach (2009), 'Large Shareholders and Corporate Policies' 22 Review of Financial Studies 3941

Dhillon, A. and S. Rossetto (2009), Corporate Control and Multiple Large Shareholders, University of Warwick Working Paper, available at www2. warwick.ac.uk/fac/soc/economics/staff/academic/dhillon/wp/submission16nov 09.pdf 
Edmans, A. (2014), Activists and Corp Governance, European Corporate Governance Institute Finance Working Paper No. 385, available at http://papers. ssrn.com/sol3/papers.cfm?abstract_id=2285781

Edmans, A. and G. Manso (2010), 'Governance Through Trading Intervention: A Theory of Multiple Activists' 24 Review of Financial Studies 2395

Gad, S. (2013), 'What are Hedge Funds?', Forbes, available at www.forbes.com/ sites/investopedia/2013/10/22/what-are-hedge-funds/

Gilson, R. and J. Gordon (2013), 'The Agency Costs of Agency Capitalism: Activist Investors and the Revaluation of Governance Rights' Columbia Law Review 863

Hayden, G. and M.T. Bodie (2010), 'Shareholder Democracy and the Curious Turn toward Board Primacy' 51 William and Mary Law Review 2071

Hirschman, A.O. (1970), Exit, Voice and Loyalty (Harvard University Press)

Holderness, C.G. (2003), 'A Survey of Activists and Corporate Control' 9 Economic Policy Review 51

Innovation, Science and Economic Development Canada (2016), 'The Government of Canada Introduces a Bill to Promote Corporate Transparency and Diversity' (28 September), available at http://m.marketwired.com/press-release/ government-canada-introduces-bill-promote-corporate-transparency-diversity2162359.htm

Jang, B. (2013a), 'As Harrison takes CP's top job, Ackman's coup is complete', Globe and Mail, 29 June, available at www.theglobeandmail.com/globeinvestor/as-harrison-takes-cps-top-job-ackmans-coup-is-complete/article4379406/

- (2013b), 'Activist investor Ackman unloads \$835-million CP stake', Globe and Mail, 29 October, available at www.theglobeandmail.com/report-onbusiness/ackman-unloads-835-million-cp-stake/article15065221/

Jensen, M. and W. Meckling (1976), 'Theory of the Firm: Managerial Behavior, Agency Costs and Ownership Structure' 3 Journal of Financial Economics 305

Kahan, M. and E.B. Rock (2007), 'Hedge Funds in Corporate Governance and Corporate Control' 155 University of Pennsylvania Law Review 1021

Katelouzou, D. (2013), 'Myths and Realities of Hedge Fund Activism: Some Empirical Evidence' 7 Virginia Law and Business Review 459

Kimber Report (1965), Report of the Attorney-General's Committee on Securities Legislation in Ontario (Queen's Printer)

Kulpa, A. (2005), 'The Wolf in Shareholder's Clothing' 6 UC Davis Business Law Journal 4

Lipton, M. and W. Savitt (2007), 'The Many Myths of Lucian Bebchuk' 93 Virginia Law Review 733

Murphy, M. (2009), 'Restoring Trust in Corporate America: Toward a Republican Theory of Corporate Legitimacy' 5 New York University Journal of Law and Business 415

- (2011), 'Assuring Responsible Risk Management in Banking: The Corporate Governance Dimension' 36 Delaware Journal of Corporate Law 121

Ontario Securities Commission (2013), 'Notice and Request for Comment: Proposed NI 62-105 Security Holder Rights Plans, Proposed Companion Policy 62-105CP, and Proposed Consequential Amendments', NI 62-105, available at www.osc.gov.on.ca/documents/en/Securities-Category6/ni_2013 0314_62-105_security-holder-rights-plan.pdf 
Rose, P. and B. Sharfman (2014), 'Shareholder Activism as a Corrective Mechanism in Corporate Governance' Brigham Young University Law Review 1015

Shleifer, A. and R.W. Vishny (1986), 'Large Shareholders and Corporate Control' 94 Journal of Political Economy 461

Skeel Jr, D.A., V. Chahar, A. Clark et al. (2011), 'Inside-Out Corporate Governance' 37 Journal of Corporation Law 147

Stout, L. (2012), The Shareholder Value Myth (Berret-Koehler Publishing)

- (2013), 'On the Rise of Shareholder Primacy, Signs of Its Fall, and the Return of Managerialism (In the Closet)' 36 Seattle University Law Review 1169

The Panel on Takeovers and Mergers (2008), 'The City Code on Takeovers and Mergers', available at www.thetakeoverpanel.org.uk/wp-content/uploads/2008/ 11/code.pdf? $v=120916$

TMX Money (2013), 'Share Price Data', available at www.tmxmoney.com/en/ index.html

Vanderpol, S. and E.J. Waitzer (2012), 'Addressing the Tension between Directors' Duties and Shareholder Rights: A Tale of Two Regimes' 50 Osgoode Hall Law Journal 177

Winton, A. (1993), 'Limitation of Liability and Ownership Structure of the Firm' 48 Journal of Finance 487 